Vol. 02 No. 2 Desember 2018

e-ISSN : 2549-6352, p-ISSN: 2549-6344

Web: jurnal.iain-padangsidimpuan.ac.id/index.php/JurnalGender

\title{
GENDER DAN SISTEM KEKERABATAN MATRILINIAL
}

\author{
1. Esli Zuraidah Siregar; 2. Ali Amran \\ IAIN Padangsidimpuan \\ 1. esli.zuraidah@gmail.com; 2.amranhsbz2@gmail.com
}

\begin{abstract}
Abstrak: Matrilinial is one of the oldest kinship systems found in Indonesia, and the world. This system adheres to kinship systems and inheritance systems from the maternal lineage. in the matrilinial kinship system, women have a special place and play a significant role in their community compared to women who adhere to the patrilinieal system. In the matrilineal kinship system, men and women have their respective obligations and responsibilities according to their gender. In this case they have a balanced position, namely men occupying positions as supervisors and protectors who are given an honorable position as mamak (mother's brother), while women have access as ownership. In a sense, women get privileged places, and men become powerful figures. However, in making decisions, men and women have the same position.
\end{abstract}

Keywords: Gender, Matrilineal Relationship

\section{A. Pendahuluan}

Indonesia merupakan negara multikultural, yang ditandai dengan keberagaman suku, budaya, adat istiadat, serta sistem kekerabatan yang menarik. Keberagaman yang telah ada merupakan suatu anugerah yang diberikan Allah SWT yang sudah sepatutnya dijaga dan dilestarikan. Sistem kekerabatan merupakan salah satu keberagaman yang dimiliki Indonesia. Terdapat dua sistem kekerabatan yang dianut masyarakat dunia, yakni matrilinial dan matrilinial. Patrilinial merupakan sistem kekerabatan dengan orang lain karena adanya keterkaitan dengan garis 
keturunan dari pihak ayah, sedangkan matrilinial adalah sistem kekerabatan yang memiliki keterikatan dengan garis keturunan dari pihak ibu. (Mawardi \& Nur Hidayati, 2009:213).

Penduduk Indonesia yang terdiri dari beragam etnis masyarakat, sebahagian besar menganut sistem kekerabatan patrilinial. Jarang sekali kelompok etnis yang memiliki sistem kekerabatan matrilinial di berbagai belahan dunia, barangkali hanya dua atau tiga, antara lain, di Afrika Selatan dan India. Sistem kekerabatan matrilinial tergolong unik dan banyak menarik perhatian masyarakat Indonesia sampai manca Negara. Disaat diskriminasi antara laki-laki dan perempuan diberbagai tempat di belahan bumi masih semarak, termasuk di Indonesia. Kekerabatan matrilinial justru berusaha meninggikan derajat perempuan.

Kaum wanita seringkali dianggap sebagai kaum kelas dua, yang posisinya di bawah keberadaan kaum laki-laki. Namun, dalam sistem kekerabatan Matrilinial, wanita mengambil tempat penting dalam perikehidupan masyarakat, dipuja, dan dihormati. Hal ini termasuk alam pikiran tradisional Indonesia yang tidak pernah mengecilkan peran wanita dalam kehidupan, ini merupakan salah satu pemikiran para leluhur kita terhadap gender.

Istilah gender, dijelaskan sebagai bentuk perbedaan antara lakilaki dan perempuan hasil dari kontruksi sosio-budaya. Dengan kata lain, ia merujuk kepada sifat maskulin dan feminism yang dipengaruhi oleh budaya, simbolik dan pengenalan diri. Pada hakikatnya gender membahas tentang laki-laki dan perempuan.

Gender merupakan salah satu isu, yang hangat dan menarik untuk diperbincangkan. Istilah gender mengandung arti seperangkat sikap, peran, tanggung jawab, fungsi, hak dan perilaku yang melekat pada diri laki-laki dan perempuan akibat bentukan budaya dan lingkungan masyarakat tempat dimana manusia itu tumbuh dan dan dibesarkan, sehingga dikenal dengan gender yang berbeda antara laki-laki dan perempuan.

Perbedaan gender merupakan hal yang wajar dan biasa, atau suatu kewajaran selama ia tidak menimbulkan ketidakadilan gender. Ketidakadilan gender akan menyebabkan pembagian peran dan tanggung jawab yang berlebih pada salah satu pihak, yakni perempuan atau lakilaki. Perbedaan gender ternyata telah menyebabkan munculnya 
ketidakadilan gender yang terjadi dalam keluarga (kekerabatan) dan masyarakat. Ketidakadilan gender memjadi sesuatu yang perlu diperjuangkan untuk kesetaraan dan keadilan.

Gender adalah kemitrasejajaran antara laki-laki dan perempuan dalam aspek sosiologi, sistem nilai, wawasan, strategi pembangunan, selaras, serasi seimbang. Kesetaraan gender berarti kondisi yang sama antara laki-laki dan perempuan dalam memperoleh hak sebagai manusia. Namun, berdasarkan perkembangannya, pembahasan mengenai gender lebih difokuskan kepada perempuan. Skenario ini disebabkan golongan perempuan telah lama dipinggirkan dalam sejarah dan budaya masyarakat. Isu bias gender lebih banyak berhubungan dengan ketidakadilan dan diskriminasi terhadap perempuan.

Berbagai institusi telah dibentuk untuk melindungi hak-hak perempuan, namun, dominasi institusi negara (penguasa) terkadang justru menyebabkan melemahnya peran institusi masyarakat lokal, hingga kontrol rakyat terhadap negara pun semakin mengecil. Banyak institusi yang berkedok untuk melindungi perempuan, namun justru melemahkan posisi perempuan itu sendiri. Isu penting dalam sistem kekerabatan matrilineal sesuangguhnya adalah keadilan dan kesetaraan gender. Perempuan tidak hanya memiliki akses dalam wilayah publik, melainkan juga wilayah domestik. Dalam artian laki-laki dan perempuan seharusnya mengetahui peran dan kewajiban berupa tanggung jawab masing-masing yang harus dilaksanakannya. Karena pada hakikatnya, kesetaraan gender adalah menempati peran sesuai posisi gendernya.

\section{B. KAJIAN TEORI DAN PEMBAHASAN}

\section{Gender dan Kekerabatan Matrilinial}

Gender berasal dari Bahasa Inggris berarti kelamin (Jhon M. Echols dan Hassan Shadily, 1983:265). Dalam Webster's New World Dictionary, gender diartikan sebagai perbedaan yang tampak antara laki-laki dan perempuan dilihat dari segi nilai dan tingkah laku (Victoria Naufeldt, 1984:561) Gender merupakan suatu konsep dasar untuk pengaruh factor budaya dan kehidupan kolektif dalam laki-laki dan perempuan.

Berdasarkan defenisi tersebut, dapat dipahami bahwa gender adalah suatu konsep yang digunakan untuk mengidentifikasi perbedaan antara laki-laki dan perempuan dilihat dari segi pengaruh sosial budaya. Gender dalam hal ini adalah suatu bentuk rekayasa masyarakat, bukan hanya suatu hal yang dianggap kodrati. Dalam konsep tersebut, gender harus dibedakan dari jenis kelamin (seks). Jenis kelamin merupakan 
suatu pensifatan manusia yang ditentukan secara biologis yang melekat pada jenis kelamin tertentu.

Istilah gender diperkenalkan oleh para ilmuwan sosial untuk menjelaskan perbedaan antara laki-laki dan perempuan yang bersifat bawaan sebagai ciptaan Tuhan dan yang bersifat bentukan budaya yang dipelajari dan disosialisasikan sejak kecil. Perbedaan ini sangat penting, karena selama ini sering seklai mencampurkan adukan cirri-ciri manusia yang bersifat kodrati dan yang bersifat bukan kodrati (gender). Perbedaan peran gender ini sangat membantu untuk memikirkan kembali tentang pembagian peran yang selama ini dianggap telah melekat pada laki-laki dan perempuan untuk membangun gambaran relasi gender yang dinamis serta tepat serta cocok dengan kenyataan yang ada dalam masyarakat. Perbedaan gender secara sosial telah melahirkan perbedaan peran perempuan dan laki-laki dalam masyarakat.

Kata gender sebagai perbedaan peran, fungsi, status, dan tanggung jawab antara laki-laki dan perempuan sebagai hasil bentukan (konstruksi) sosial budaya yang tertanam lewat proses sosialisasi dari satu generasi ke generasi berikutnya. Dengan demikian istilah gender adalah hasil kesepakatan antar manusia tidak bersifat kodrati. Oleh karenanya gender bervariasi dari satu tempat ke tempat ang lain, dan dari satu waktu ke waktu yang lain. Gender tidak selamanya bersifat kodrati, karena dapat berubah dan dapat dipertukarkan pada manusia satu ke manusia lainnya tergantung waktu dan kebudayaan setempat.

Gender sangat dipengaruhi oleh kebudayaan masyarakat setempat. Bisa jadi aturan adat dan kebudayaan yang ada disuatu tempat dinilai diskrimatif oleh daerah lain, hal ini tidak dapat disalahkan mengingat budaya Indonesia yang beragam sehingga memiliki pandangan yang berbeda-beda terhadap gender laki-laki dan perempuan. Gender bisa berubaha tergantung budaya dan kondisi sosial masyarakat. Nilainilai pada budaya kebudayaan masyarakat menentukan seperti apa peran gender seseorang. Oleh karenanya gender dan kebudayaan selalu berdampingan. Seperti yang terdapat dalam masyarakat yang menganut sistem kekerabatan matrilineal, yakni sistem kekerabatan yang mengambil garis keturunan dari ibu.

Matrilinial berasal dari dua kata bahasa Latin, yaitu mater yang berarti Ibu, dan Linie yang berarti garis. Matrilinial berarti garis ibu, sistem kekerabatan matrilinial merupakan suatu masyarakat yang mengatur alur keturunan dari pihak ibu dan akan mempengaruhi suku, marga anak yang dilahirkan, sistem pewarisan dan sebagainya. Kata 
matrilinial sering disamakan dengan matriarkhat atau matriakhi, meski pada dasarnya memiliki perbedaan arti.

Ahli hukum lazim disimpulkan dalam kata-kata rumusan Matrilinial, geologis dan teritorial. Pada sistem kekerabatan matrilineal, garis keturunan adalah ibu dan wanita: anak-anak hanya mengenal ibunya dan saudara ibunya, sedangkan ayah dan keluarganya tidak masuk dalam Clan anaknya, karena ayah termasuk Clan ibunya pula. Para ahli antropologi juga sependapat, bahwa garis-garis keturunan matrilineal merupakan garis keturunan tertua dari bentuk garis keturunan lainnya. Salah seorang dari ahli tersebut bernama Wilken yang terkenal dengan teori Evolusinya. Wilken mengemukakan bahwa proses dari garis keturunan. Garis keturunan ini memiliki proses pertumbuhan sebagai berikut: (1) garis keturunan ibu, (2) garis keturunan ayah, (3)garis keturunan orang tua (Amir, 2006:8-9). Menurut teori evolusi, garis keturunan ibu merupakan garis keturunan tertua dan kemudian garis keturunan ayah. Selanjutnya si anak tidak hanya mengenal garis keturunan ibunya, tetapi juga garis keturunan ayahnya. Teori ini menitikberatkan terhadap evolusi kehidupan manusia.

Pada masa lalu pergaulan antara laki-laki dan perempuan masih bebas, belum menganal norma-norma perkawinan. Jadi, untuk memudahkan silsilah seorang anak dengan berdasarkan kelahiran, berdasarkan alam yang berkembang menjadi guru, dalam kenyataan, yang beranak itu adalah wanita atau betina. Dengan demikian, keturunan berdasarkan perempuan mendapat tempat yang pertama. Dalam kenyataannya, sampai saat ini masih ada beberapa suku di Indonesia bahkan di Dunia yang masih menganut sistem kekerabatan ini. Di samping itu, garis keturunan ibu atau matrilineal sangat berkaitan dengan sistem kewarisan. Katurunan bukan sekedar menentukan garis keturunan anak-anaknya, melainkan berkaitan dengan adat istiadat dan posisi perempuan dalam adat dan bahkan hak warisnya.

Garis keturunan sangat erat kaitannya dengan penguasaan sumber daya yang bernilai ekonomis. Filosofisnya, memberikan akses ekonomi yang sangat tinggi kepada perempuan. Hal ini menunjukkan adanya kedudukan perempuan yang sangat kuat. Perempuan dilindungi oleh system pewarisan matrilinial dan pola menetap setalah menikah yang bersifat matrilokal. Pembagian peran secara tradisional dalam system matrilinial telah menempatkan posisi perempuan sebagai tokoh kunci dalam mengelola tanah dan rumah sebagai tokoh kunci (Lany Verayanti, 2003: 13) 
Akses perempuan terhadap sumber daya alam (ekonomi) menyebabkan laki-laki tidak memiliki hak atas harta. Dampak positif dari fenomena ini adalah banyaknya laki-laki yang pergi dari kampung halamannya untuk merantau dengan dalih ekonomi. Terdapat beberapa factor yang menyebabkan laki-laki penganut system matrilinial merantau antara lain: Faktor fisik (Alam), pendidikan, politik, daya tarik kota dan dan sebagainya, akan tetapi adat matrilinial adalah persoalan penting mengapa mereka pergi merantau. Di sisi lain bagi laki-laki yang berkeluarga (mempunyai anak istri), tidak begitu canggung dan ragu bagi mereka untuk meninggalkan keluarga. Karena istri dan anak-anak yang mereka tinggalkan mampu dan bisa survive dengan harta pusakan istri mereka di kampong halamannya. Tidak jarang perempuan penganut sistem ini sudah terbiasa mengatur dan menjadi pemimpin dalam keluarganya ketika laki-laki tidak berada di tengah-tengah keluarga (Mochtar Naim, 1984: 249)

Baik di Indonesia maupun di berbagai Negara lain dunia, penganut sistem kekerabatan matrilinial merupakan kelompok minoritas. Komunitas penganut sistem kekerabatan ini hanya merupakan komunitas kecil atau kelompok kecil, sangat jarang ditemukan dalam komunitas besar. Faktanya sudah banyak dari penganut ini yang beralih pada sistem kekerabatan patrilinial karena pengaruh-pengaruh dari luar, baik ia lingkungan, agama, dan pola fikir yang semakin maju, dan mungkin memiliki keterkaitan dengan adanya isu kesetaraan gender yang akhirakhir ini semakin membuming.

Branislaw Malinowsky dalam buku karangan Muhammad Radjab, ada beberapa ciri-ciri sistem kekerabatan matrilinial yang menjadi cirri khas sistem yang dianut, yakni:

1. Keturunan dihitung menurut garis ibu

2. Suku terbentuk menurut garis ibu

3. Perkawinan exogamy, artinya setiap orang diharuskan kawin dengan orang di luar sukunya

4. Pembalasan dendam (?) merupakan satu kewajib an bagi seluruh suku

5. Kekuasaan di dalam suku menurut teori terletak dsi tangan ibu,meskipun jarang sekali terjadi

6. Yang sebenarnya berkuasa adalah saudara laki-laki

7. Perkawinan bersifat matrilokal, yaitu suami mengunjungi rumah isteri

8. Hak-hak pusaka diwariskan kepada perempuan berdasarkan garis keturunan ibu (Muhamad Radjab, 1969:210-211). 
Pembahasan di atas, yang tidak ditemui sekarang adalah pembalasan dendam yang merupakan tata kewajiban seluruh suku, mungkin ini terjadi pada masa lalu dan sesuai perkembangan zaman dan pengaruh norma agama yang semakin kuat, tradisi itu kian mengikis. Terdapat beberapa penganut sistem kekerabatan Matrilinial yang terdapat di Indonesia, yakni:

1. Suku Enggano, suku asli yang mendiami pulau Enggano beserta empat pulau disekitarnya. Pulau ini berada di Bengkulu dan salah satu pulau terluar milik Indonesia.

2. Suku Sakai, salah satu suku asing Indonesia. Suku ini hidup di pedalaman Riau, suku ini termasuk penganut matrilinial yang keras (diterapkan secara penuh)

3. Suku Ocu, salah satu ku yang mendiami kabupaten Kampar, Riau. Sampai saat ini masih ada perdebatan apakah suku Ocu merupakan bagian dari Melayu atau Minangkabau.

4. Suku Kerinci, suku Kerinci marupakan suku penganut sistem matrilinial terbanyak di Indonesia setelah suku Minangkabau. Komuntas ini mendiami daerah kerinci, suku ini merupakan salah satu suku tertua di dunia.

5. Suku Minangkabau, suku Minangkabau merupakan populasi penganut sistem matrilinial terbesar di Indonesia, suku Minangkabau terdapat di Sumatera Barat, hamper seluruh wilayah Sumatera Barat menganut sistem kekerabatan Matrilinial.

Sistem kekerabatan matrilineal berbeda dengan perlakuan pada umumnya yang diterapakan dalam kekerabatan Patrilinial, dibeberapa daerah bahkan perempuan tidak mendapat pengakuan budaya ( T.0 Ihromi, 200-2016) Perempuan dalam sistem ini amat ditinggikan, baik dalam adat, keseharian maupun dalam pembagian harta warisan. Saat bias gender menjadi isu terhangat banyaknya pendiskriminasian terhadap kaum perempuan, sistem ini justru meninggikan posisi perempuan, sebagaimana seharusnya perempuan diperlakukan.

Perempuan menduduki posisi yang istimewa dalam sistem ini, karena keturunan dan kesatuan keluarga didasarkan pada garis keturunan ibu (Idrus Hakimi, 2004: 120) mereka memiliki kedudukan istimewa tentang keturunan, harta warisan (rumah, sawah, ladang) dan bahkan dalam adat, bukan berarti laki-laki tidak mendapat tempat dalam adat. Laki-laki dipandang sepintas lalu tidak mempunyai rumah dan hak ekonomi dari warisan, sebenarnya dia mempunyai dua rumah dan dua 
sumber ekonomi, rumah saudaranya yang perempuan dan rumah istrinya, begitu juga dengan sawah lading.

Sistem ini mengatur sedemikian rupa dan memperhitungkan hakhak bagi perempuan, termasuk sumber ekonomi sebgaai kelangsungan hidupnya dimasa yang akan datang, karena sistem ini dilengkapi dengan syarat ekonomi dan kediaman. Dalam aturan pernikahan, apabila terjadi perceraian antara suami istri. Sang suami yang pergi dari rumah istri, sehingga perempuan yang dicerai suaminya tidak mengalami kesulitan dalam hal ekonomi dan tempat tinggal. Di sisi lain, laki-laki di rumah istrinya turut mengelola usaha keluarga istrinya, dan secara bersamaan ia juga memperoleh hak dari saudaranya. Berdasarkan kenyataan tersebut, laki-laki dan perempuan dalam sistem ini memiliki hak ekonomi yang sama, namun berusaha menempatkan posisi perempuan diposisi yang lebih aman.

Peran perempuan dalam sistem kekerabatan matrilineal memiliki posisi yang startegis dalam membina dan mensejahterakan hidup perempuan, akan tetapi bukan berarti tidak member hak kepada laki-laki. Dalam hal ini, posisi laki-laki dianggap lebih kuat dan lebih mumpuni untuk memperoleh kehidupan yang layak tanpa mengandalkan harta warisan keluarganya. Salah satu cirri khas dari laki-laki yang menganut sistem kekerabatan matrilineal, laki-laki biasanya banyak yang merantau ke luar daerah dan cukup banyak yang sukses di daerah perantauan.

Posisi perempuan, cukup startegis dan menentukan dalam pengambilan keputusan, bahkan suatu kegiatan tidak akan terlaksana tanpa keterlibatan perempuan. Dalam hal ini mereka mempercayai bahwa perempuan memiliki kelembutan dan ketegasan dalam mengambil keputusan. Contohnya, apabila ada penjualan, pembelian harta, hibah, pagang gadai, maka mereka selalu diikut sertakan. Dalam setiap musyawarah yang diadakan di daerah penganut site mini, harus mendapat persetujuan dalam memulai acara. Acara tidak dapat dilangsungkan tanpa persetujuan tokoh perempuan di daerah tersebut.

Perempuan menjalankan dua peran sekaligus, yaitu peran domestik dan publik. Peran domestik yaitu peran yang dimainkan dalam rumah tangga, sebagai seorang ibu dari anak-anaknya, istri dari suaminya dan sebagai saudara dari saudaranya, sedangkan peran public yakni peran sebagai seseorang yang dapat membantu ekonomi keluarga. 
Laki-laki dalam sistem kekerabatan ini juga memiliki peran yang tidak kalah penting dengan perempuan dalam keluarga dan adat istiadat. Ia berperan sebagai ayah untuk anak-anaknya, sebagai seseorang yang bertanggung jawab terhadap keponakan dari saudaranya, sebagai suami sekaligus kepala keluarga, dan sebagai pengawas, pelindung, dan pemelihara harta saudaranya. Selain peran dalam keluarga, laki-laki juga memiliki peran penting dalam masyarakatnya, yakni sebagai alim ulama, penghulu, cerdik pandai (Mas'ud Abidin, 2000). Laki-laki dituntut menjadi figur pemimpin yang menjadi tauladan dalam kehidupan seharihari, panutan yang sejalan dengan sikap dan perilaku berdasarkan ajaran Islam (Jamaris, 2004:127)

Dalam sistem Matrilinial, laki-laki yang mengikut kepada perempuan. Dan bahkan laki-laki yang berperan sebagai suami hanya diperlakukan sebagai tamu dalam keluarga. Secara tradisi setidaknya tanggung jawabnya sebagai wali dari garis keturunannya dan pelindung atas harta benda garis keturunan itu. Seorang laki-laki yang termasuk dalam sistem ini harus menahan dirinya untuk menikmati hasil tanah dan harta pusaka orang tuanya. Hal ini merupakan sebagai bentuk kasih sayang saudara laki-laki kepada saudara perempuannya sebagai manusia yang dianggap lemah. Karena mereka beranggapan, anak laki-laki akan mampu menopang hidup dan mencari kekayaan untuk dirinya sendiri kelak di masa mendatang, maka tidak jarang anak-laki-laki penganut Matrilinial berbondong-bondong pergi merantau dan mencari penghidupan di daerah lain yang jauh dari daerah asalnya. Dan kebiasaannya banyak dari mereka yang mengalami kesuksesan di perantauan berkat kegigihan mereka.

Laki-laki penganut sistem ini cenderung lembut, namun tegas, apalagi saat dihadapkan dengan perempuan. Hal ini sebagai bentuk perlindungan mereka terhadap perempuan. Walau pun dalam masyarakat, ayah bahkan hanya diperlakukan sebagai tamu, bukan anggota garis keturunan anaknya. Mereka mengkuatirkan kedudukan perempuan dalam stara masyarakat, sebagaimana Islam memperjuangkan hak perempuan, begitu juga laki-laki penganut sistem ini berusaha mengangkat harkat dan martabat perempuan serta hakhaknya, bahkan rela memberi hak yang seharusnya didapatkan oleh mereka (laki-laki) sebagai bentuk rasa tanggung jawab terhadap saudara perempuannya dengan cara mengistimewakan mereka.

Perbedaan gender sesungguhnya tidaklah menjadi masalah sepanjang tidak melahirkan ketidakadilan gender. Namun, ternyata 
perbedaan gender telah melahirkan berbagai ketidakadilan, baik bagi kaum perempuan maupun pada kaum laki-laki. Ketidakadilan gender termani-festasikan dalam berbagai bentuk ketidakadilan. Dalam sistem ini, apabila dilihat secara kasat mata, terjadi ketidakadilan atau pendiskridatan terhadap kaum laki-laki, perempuan terlalu diistimewakan sehingga kaum laki-laki seakan terkorbankan, walaupun pada dasarnya telah ada unsure kerelaan dari laki-laki tentang kebiasaan yang diajarkan dan dilaksanakan secara turun temurun.

Bahkan dalam upacara acara adat, perempuan mendapat tempat penting dalam jajaran adat tersebut. Seperti dalam adat Minangkabau yang merupakan penganut sistem Matrilinial terbanyak di Indonesia, bundo kanduang mendapat tempat yang mumpuni dikalangan tokoh adat. Suatu acara adat tidak dapat dilaksanakan tanpa kehadiran bundo kanduang sebagai tokoh adat.

Kajian gender sampai saat ini masih hangat diperbincangkan baik dikalangan masyarakat biasa, politisi maupunn intlektual. Namun belakangan, gender lebih terfokus pada istilah saling mengungguli antara laki-laki dan perempuan, atau saling terdiskreditkan. Hal ini berefek pada struktural dan sistem gender yang lambat laun mulai terbiasa saling berlaku tidak adil dan sudah tidak dapat dirasakan, bahwa itu merupakan suatu kesalahan.

Ketidakadilan gender membentuk struktur hubungan produksi dan reproduksi dalam kelas-kelas yang berbeda. Contohnya: laki-laki mempunyai peran utama sebagai pencari nafkah rumah tangga sekaligus memainkan peranan yang cukup penting dalam menciptakan reproduksi pekerjaan yang tidak berbayar dalam ruang domestik yang umumnya dikaitkan dengan fungsi biologis perempuan sebagai perawat keluarga. Secara kemasyarakatan peran ini diadopsi juga dalam kaitan tanggung jawab peningkatan kualitas sumber daya manusia.

Terjadi ketidakadilan sumber daya laki-laki dan perempuan dalam hal menjalankan tanggung jawab. Perempuan merasa diperlakukan tidak adil di masyarakat karena adanya konsep gender membuat sebagian feminis ahli psikologi sadar dan menganalisis kesalahan dari teori gender. Mereka mengajak seluruh masyarakat terutama kaum perempuan untuk sadar bahwa selama ini mereka diperlakukan tidak adil oleh konsep gender dan mengembangkan suatu konsep baru yang mengikis perbedaan perlakuan bagi perempuan dan laki-laki. Padahal pada fitrahnya, laki-laki merupakan pelindung perempuan dan menjaga harkat dan martabat perempuan, sedangkan perempuan mendapat posisi yang 
harus dilindungi. Namun, hal ini menjadi persoalan yang patut dibahas secara jelas oleh kaum perempuan, apalagi ia berperan sebagai wanita karir, atau wanita yang bekerja di luar rumah, yang bahkan mungkin memiliki penghasilan yang lebih banyak dari suaminya.

Dalam sistem kekerabatan matrilineal, perempuan tidak harus melakukan perjuangan gender seperti yang terjadi di daerah lain, karena sistem ini telah menyediakan semuanya bagi perempuan. Sistem ini masih tetap dipertahankan meski sistem patriliniael juga diperkenalkan oleh Islam sebagai sebuah sistem kekerabatan yang lain. Konsep emansipasi wanita telah terwujud sejak lama dalam sistem penganut matrilinial.

Pada kenyataannya, konsep atau ideology gender membuat manusia jadi terkotak-kotak. Konsep gender merupakan suatu konsep baru yang diharapkan dapat memberi kesempatan dan kedudukan yang sejajar bagi perempuan maupun laki-laki untuk membuat keputusan bagi dirinya sendiri tanpa harus berorientasi pada konsep gender (Millar, 1992). Konsep gender bagai sebuah referensi pembelaan bagi kaum perempuan. Dalam konsep matrilinial, laki-laki tetaplah berperan sebagai sosok yang berusaha menghidupi istri dan anak-anaknya dan perempuan tetap sebagai pengayom bagi anak-anaknya. Namun, derajat perempuan dalam sistem ini ditinggikan dan dihormati.

\section{Gender Dalam Persfektif Islam}

Dalam Islam diajarkan posisi laki-laki lebih tinggi dibanding perempuan, akan tetapi bukan berarti derajat perempuan lebih rendah dibandingkan dengan laki-laki. Laki-laki dan perempuan memiliki tugas dan tanggung jawab masing-masing sesuai kodrati. Allah meninggikan derajat wanita, dan menjadikannya makhluk lemah yang harus dilindungi laki-laki. Sistem kekerabatan matrilineal melindungi perempuan dengan meninggikan derajat perempuan dalam adat istiadat, maupun dalam hal kewarisan. Dalam sistem ini perempuan merupakan manusia yang harus ditinggikan derajatnya. Apabila ditinjau secara agama, hal ini adalah tema sentral sekaligus prinsip pokok egalitarian dalam Islam, yakni persamaan antar manusia, baik laki-laki dan perempuan maupun antar bangsa, suku, dan keturunan. Hal ini diisyaratkan dalam QS. al-Hujurat: 13

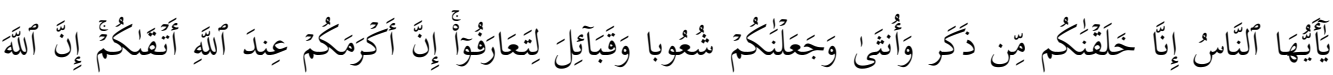
عَلِيٌْ خَبِير 
"Hai manusia sesungguhnya kami menciptakan kamu dari seorang laki-laki dan seorang perempuan dan menjadikan kamu berbangsabangsa dan bersuku-suku supaya kamu saling kenalmengenal. Sesungguhnya orang yang paling mulia diantara kamu di sisi Allah adalah orang yang paling bertakwa diantara kamu"

Ayat tersebut memberikan gambaran tentang persamaan antara laki-laki dan perempuan baik dalam hal ibadah (dimensi spiritual) maupun dalam aktivitas sosial (urusan karier profesional). Ayat tersebut juga sekaligus mengikis tuntas pandangan yang menyatakan bahwa antara keduanya terdapat perbedaan yang memarginalkan salah satu diantara keduanya. Persamaan tersebut meliputi berbagai hal misalnya dalam bidang ibadah. Bagi yang rajin ibadah, maka akan mendapat pahala lebih banyak tanpa melihat jenis kelaminnya.

Perbedaan kemudian ada disebabkan kualitas nilai pengabdian dan ketakwaannya kepada Allah swt. Ayat ini juga mempertegas misi pokok al-Qur'an diturunkan adalah untuk membebaskan manusia dari berbagai bentuk diskriminasi dan penindasan, termasuk diskriminasi seksual, warna kulit, etnis dan ikatan-ikatan primordial lainnya. Namun demikian sekalipun secara teoritis Al-Qur'an mengandung prinsip kesetaraan antara laki-laki dan perempuan, namun ternyata dalam tatanan implementasi seringkali prinsip-prinsip tersebut terabaikan.

Sehubungan dengan itu, berdasarkan ayat yang telah dipaparkan sebelumnya, menyatakan bahwa laki-laki dan perempuan mempunyai hak dan tanggung jawab yang sama, apabila ditinjau dari kajian Islam, ibadah (hubungan manusia dengan Allah) seperti dalam sholat, puasa, zakat dan haji. Hal yang sama juga berlaku dalam mu'amalat (hubungan manusia sesama manusia), misalnya hak memiliki dan mewarisi.

Dalam menjamin persamaan status kemanusiaan, Islam turut membagikan tugas dan tanggung jawab antara laki-laki dan perempuan selaras dengan perbedaan fisikologi mereka. Perbedaan antara kualitas dan kapasitas ini tidak berkaitan dengan prioritas masing-masing. Ia tidak menimbulkan ketidakadilan gender selagi hubungan kemanusiaan masih berada dalam koridor keagamaan. Ini karena kelebihan hak tertentu, diimbangi dengan penambahan kewajiban yang khusus.

Konsep gender dalam Islam dijelaskan sebagai suatu peran, fungsi tanggung jawab masing-masing sesuai kodratnya sebagai hamba Allah. Misalnya perempuan memiliki peran sebagai istri yang harus melayani suami dan anak-anak, dan laki-laki berperan sebagai kepala keluarga yang memiliki tanggung jawab mencari nafkah. Penganut sistem ini 
berusaha memuliakan perempuan dengan memberi mereka hak-hak istimewa. Sistem kekerabatan matrilinial berimplikasi pada kuatnya kedudukan perempuan di mata agama dan negara yang harus dimuliakan dan itu masih tetap berusaha dipertahankan hingga saat ini.

\section{PENUTUP}

Sistem kekerabatan matrilinial merupakan sistem kekerabatan yang mengambil garis keturunan dan pewarisan harta pusaka melalui garis keturunan ibu. Apabila dikritisi secara seksama, maka system kekerabatan yang menganut budaya matrilinial sesungguhnya mengandung nilai keadilan dan kesetaraan gender baik dalam tatanan filosofi maupun sosialnya. Sistem kekerabatan matrilinial menempatkan posisi perempuan dan laki-laki secara seimbang. Laki-laki mendapat mandat sebagai pengawas dan pelindung yang diberikan kedudukan terhormat sebagai mamak (saudara laki-laki ibu), sedangkan perempuan mendapat akses sebagai kepemilikan. Namun, dalam mengambil keputusan, laki-laki dan perempuan memiliki posisi yang sama. 


\section{DAFTAR PUSTAKA}

Amir, M.S. Adat Minangkabau: Pola dan Tujuan Hidup Orang Minang. Jakarta: PT. Mutiara Sumber Media. 2006.

Echols, Jhon dan Shadily, Hassan. Kamus Inggeris Indonesia. Cet. I: Jakarta: Gramedia, cet. XII. 1983.

Hakimy, Idrus Dt, Rajo Penghulu. Rangkaian Mustika Adat Basandi Syarak di Minangkabau. Bandung: Remaja Rosda Karya. 2004.

Jamna, Jamaris. Pendidikan Matrilineal. Guna Tama: Padang Sumbar. 2004.

Naim, Mochtar. Merantau: Pola Migrasi Minangkabau. Gajah Mada University. 1984.

Naufeldt, Victoria. Webster's New World Dictionary (New York: Nebster's New Wordl Cleveland. 1984.

Radjab, Muhammad. Sistem Kekerabatan Minangkabau. Center for Minangkabau Studies Press. 1968.

Tapi Omas Ihromi, 2000. "Budaya dan Struktur Sosial yang Partiakal: Reproduksi dan Resistensinya. Tinjauan terhadap hasil penelitian beberapa hasil penelitian tentang perempauan dalam sejumlah kebudayaan Etnik di Indonesia". Dalam perempuan Indonesia dalam masyarakat yang tengah berubah. Program Studi Kajian Wanita. Program Pascasarjana Universitas Indonesia: Jakarta.

Verayanti, Lany.dkk. Partisifasi Politik Perempuan Minangkabau dalam Sistem Masyarakat Matrilinial. Padang: LP3M 